\title{
Hope Medicine
}

\author{
Benjamin Dobbs* \\ Liberty University, USA
}

Submission: August 29, 2017; Published: August 30, 2017

*Corresponding author: Benjamin Dobbs, Liberty University, 1985 SW GOLDEN AVE, Port Saint Lucie, Florida 34953, USA, Tel: 561-735-2474; Email: benjamin_dobbs@yahoo.com

\section{Opinion}

When reviewing a source for rehabilitation and addiction medicine, I discovered in my career, by mass encountering with individuals' struggling with addictions, primarily with substance abuse, a common distinctive factor arose. That medicine can come in a form of a simple message of hope. Let us examine some different perspectives on science and the word substance. Science as according to the World Wide Web resources is defined as the following: The intellectual and practical activity encompassing the systematic study of the structure and behavior of the physical and natural world through observation and experiment (dictionary) so hope within a message that develops within a person, can become a behavioral and physical expression, which in terms grants science to have a defined foundation in the meaning and attributes of hope.

The word substance can be defined in some languages as just simply existing, and then the word medicine is written to be utilized from a substance in treating. So, our medicine can be a spiritual substance that promotes hope with influence to our scientific behaviors. In point, I am a grateful advocate for medication stabilization, or MAT - medication assistance treatment, when treating individuals' with substance abuse addiction. But, I believe that medicine can be a healing substance, found in a form of past experiences, which enter a realm of spirituality or character building information, developing an internal substance that becomes tangible with hope becoming the medicine.

\section{Introduction}

The exploration of life can be a journey, one of meaningful events that will always serve a purpose, either in the here and now, or in the latter stages of the days to come. In some ways we can examine the outcomes by our own part or piece we present through our daily living display or what role we play in the specific details of the events, but in actuality some events are not for us, but for others to receive the benefits. Through my personal journey in life I have been through challenges, obstacles, difficulties, and struggles. The pin pointing monument was being able to overcome them, but not until I was able to defeat the strong man, then deal with the strongholds and at that moment in the journey the challenges, struggles, obstacles, and difficulties became victories. I was given Grace to overcome a long period and many seasons, in fact 15 years of the struggle to addiction.

When this occurred it was only by connecting to God and exploring an in-depth relationship with Him, placing all trust, hope, and faith in His promises and purpose. In those times of struggle during the deliverance process I started to feel a sense that God had a bigger plan for my life and addiction was going to be a piece of the puzzle, but not afflicting me, but teaching others how to overcome the battle of addiction. It wasn't until having one year of sobriety that I began to notice the plan slowly being revealed into my spirit. I knew it was ministry, but didn't understand quite yet it would also be a career. It is absolutely amazing how God can turn a negative outcome and present it to be turned around into a positive outcome. The scriptures state we our overcomers by the blood of the lamb, and the word of our testimony.

I can freely say that not a day goes by in which I don't get a chance to think or speak about my testimony, but it is no longer mine it is the Lord's and to be used for my service unto Him to help others overcome. In my meditation moments I have come to realize that it is no longer the overcoming, but it is now the journey of having the understanding to help others in difficult seasons of their lives.

\section{The Benefits}

Through it all, the character that God has designed within me, is truly a breath of fresh air, that can be breath taking itself when it is deeply known of where I was, and where I am with Him today. The fruit of the Spirit is truly God's that He allows us to be partakers of to benefit others and be a true statement of the supernatural transformation process that the wonderful creator 
displays from within our human souls. The acknowledging of personal qualities has to be also a moment of self-examination and self-awareness to be humbly reviewed and explored also with proven confidence that others acknowledge in agreement that you hold onto some of the dearest character given freely to you through the determination of enduring trials that have made you who you are.

The counseling profession calls for an utmost of personal character qualities of integrity, along with diligence, compassion, understanding, emotional intelligence, gentleness, discernment, kindness, communication skills, ethics, morals, patience, and most of all Love. I personally have made an attempt to continue to dig deeper into God to have these eternal qualities, to be not only a component of my mind and heart, but a permanent fixture. The lifestyle of addiction can be a place of despair, darkness, depression, anxiety, fear, and unhealthy relationships fueled with jealousy, hatred, anger, codependency, and a place to hide and find refuge for our insecurities.

I utilize all of my character qualities in most of the encounters with clients, but some might need to be displayed in a case to case basis, not everyone has been what I have been through, and if so not everyone went through the difficult moments as I approached them. We all are different uniquely and wonderfully made to be different. When counseling it is better to validate with truth and occasionally leave out your circumstances and

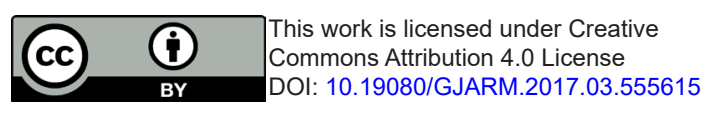

challenges and present it has a neutral source. Meaning instead of saying "What I would do, or what I did", utilize the advice tool and from a place of presenting the knowledge that your statements are evidence based and not just personal experience [1].

\section{In Closing}

All of my personal experiences of my past, the present, and future will continue to be utilized, whether I encounter an individual with AIDS, HIV, Hep. C, addiction, cancer, or just everyday struggles. I will always continue to love them the way Jesus loved me during my sickness and dark moments in life, and how He still loves me today, so I choose to do the same because it will never fail if you approach every person in this character and form of life. There is an occasional hindering process that sometimes occurs, which is when I encounter people that are not willing to put the work in to try to overcome their issues or problems. I have to understand that again not everyone is willing or wanting to whole heartily change. God is and gives us a Spirit of counsel, and through my experiences personal experiences can make some of the most understanding and effective counselors. So spread your message of hope to bring forth the medicine that can improve our rehabilitation and methods of healing.

\section{Reference}

1. (2016) Dictionary (nd) world wide web. Wikipedia the Free Encyclopedia.

\section{Your next submission with Juniper Publishers will reach you the below assets}

- Quality Editorial service

- Swift Peer Review

- Reprints availability

- E-prints Service

- Manuscript Podcast for convenient understanding

- Global attainment for your research

- Manuscript accessibility in different formats

( Pdf, E-pub, Full Text, Audio)

- Unceasing customer service

Track the below URL for one-step submission https://juniperpublishers.com/online-submission.php 